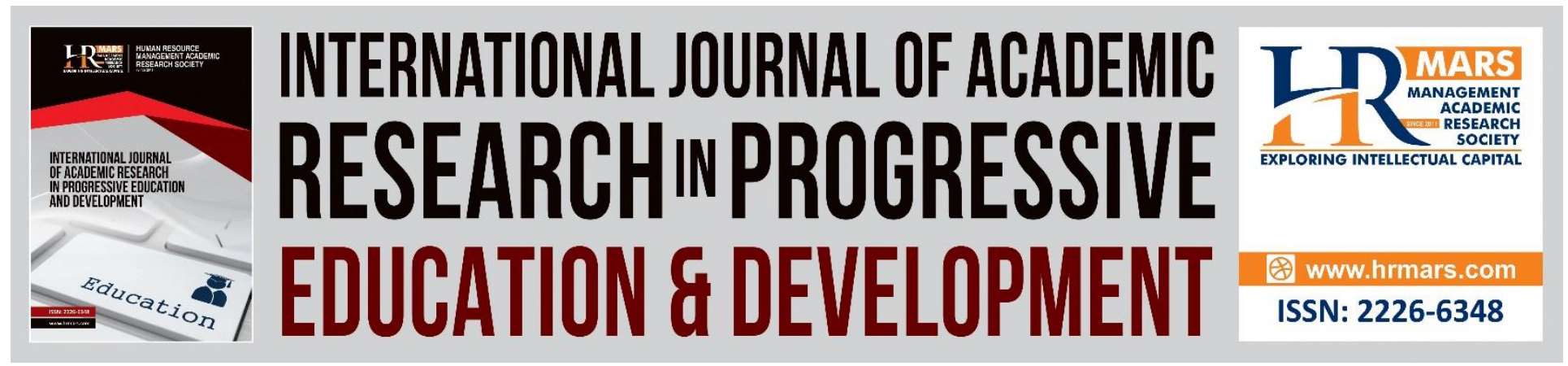

\title{
Parental Background and Students' Academic Performance: A Comparative Study in North-Central Nigeria
}

Aliyu Yunus, Mohd. Isa Hamzah, Khadijah Abdul Razak

To Link this Article: http://dx.doi.org/10.6007/IJARPED/v7-i2/4077

DOI: $10.6007 /$ IJARPED/v7-i2/4077

Received: 24 March 2018, Revised: 13 April 2018, Accepted: 07 May 2018

Published Online: 14 May 2018

In-Text Citation: (Yunus, Hamzah, \& Razak, 2018)

To Cite this Article: Yunus, A., Hamzah, M. I., \& Razak, K. A. (2018). Parental Background and Students' Academic Performance: A Comparative Study in North-Central Nigeria. International Journal of Academic Research in Progressive Education and Development, 7(2), 1-15.

\section{Copyright: (C) 2018 The Author(s)}

Published by Human Resource Management Academic Research Society (www.hrmars.com)

This article is published under the Creative Commons Attribution (CC BY 4.0) license. Anyone may reproduce, distribute, translate and create derivative works of this article (for both commercial and non-commercial purposes), subject to full attribution to the original publication and authors. The full terms of this license may be seen

at: http://creativecommons.org/licences/by/4.0/legalcode

Vol. 7, No. 2, April 2018, Pg. 1 - 15

http://hrmars.com/index.php/pages/detail/IJARPED

JOURNAL HOMEPAGE

Full Terms \& Conditions of access and use can be found at http://hrmars.com/index.php/pages/detail/publication-ethics 


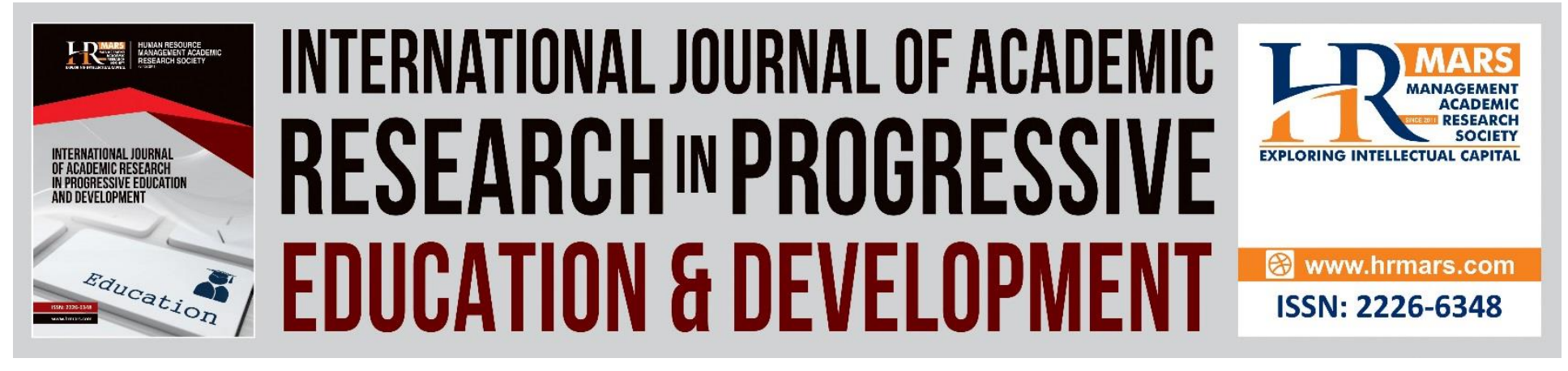

\title{
Parental Background and Students' Academic Performance: A Comparative Study in North-Central Nigeria
}

\author{
Aliyu Yunus \\ Department of Arts Education, Faculty of Education, University of Ilorin, Nigeria \\ Email: muqadamyunus@gmail.com
}

Dr. Mohd. Isa Hamzah

Department of Community Education \& wellbeing, Faculty of Education, University Kebangsaan

Malaysia (UKM),

Email: isa_hamzah@ukm.edu.my

Dr. Khadijah Abdul Razak

Department of Education Leadership \& Policy, Faculty of Education, University Kebangsaan

Malaysia (UKM),

Email: khadijah.razak@ukm.edu.my

\begin{abstract}
This paper examined the academic performance of male and female Islamic Studies students based on their parental background factors such as education, occupation, income and involvement in senior secondary schools in North-Central Nigeria. Four research hypotheses were outlined. This study was a quantitative research and questionnaire was used as an instrument for data collection while 384 respondents were advantageously selected as sample. The opinions of experts were used to establish the validity of the instrument. Indeed, for the reliability of an instrument, a Test-retest method was conducted for the questionnaire and the results were used to calculate the reliability coefficient which was 0.76 . The Statistical Package for the Social Sciences vision 23.0 was used for data analysis. The outcome of this paper indicates that there is no significant difference in scores for both male and female respondents in relation to these parental factors (education 0.09>0.05, occupation 0.29>0.05 and involvement 0.31> 0.05). It is only parental income which was shown as different between the male scores $(M=23.09 ; S D=4.69)$ and female scores $(M=20.83 ; S D=4.74)$. It shows that students whose parents with educational background and who engage in respected occupation support both male and female secondary school students equally particularly in Islamic Studies. In addition,
\end{abstract}



DEVELOPMENT

Vol. 7, No. 2, April 2018, E-ISSN: 2226-6348 @ 2018 HRMARS

only parental income has shown the difference between mean score for both male and female secondary school students in Islamic Studies in north-central. Therefore, this study contributes to existing knowledge by comparing academic performance of male and female students in Islamic Studies based on dimension of parental background such as education, occupation, income, and involvement in north-central geo-political zone of Nigeria. It is recommended that the government, school management, Islamic Studies teachers and parents should play collaborating roles on female education in order to boost their performance in Islamic Studies in secondary schools in North-Central Nigeria. Irrespective of the learners' parental background, parents should also assist and encourage their female students in leading them towards achieving outstanding academic performance in Islamic Studies in secondary schools in North-Central Nigeria.

Keywords: Parental Background, Comparative, Academic Performance, Male, Female.

\section{Introduction}

In some African countries, academic performance based on gender has been a major research area carried out by several scholars. Many studies have discussed how the different gender perform differently in various academic endeavour. They focus on different variables that can hinder academic grades for male and female students. For instance, students from Ghana and South Africa are strongly influenced by higher qualifications of their parents (Simelane, 1996, Guo \& Harris, 2000; Kamau, 2013). They note that a male child with high grades can come from a reputable family where every facility is provided for him unlike that of a female child. However, in some East African countries like Somalia, Kenya and Ethiopia, students whose parents earn higher income perform better than their counterparts (Venkatesh, 1999; Pamela \& Kean, 2010). They further emphasize that, the majority of parents invest a substantial part of their time and money on the development of their male children in the hopes that they will eventually be useful for themselves, society and as well the whole country at large.

Nigeria is one of the biggest countries in Africa with over 180 million people in population. It has been demonstrated that Nigeria's economy is competitive at the global platform and it is currently affecting different sectors, especially the educational sector. However, if the economy is alternatively affected, it will have a great effect on the educational system and other aspects of the nation. For instance, in a situation where parents do not pay attention to their children's education or get a job to take good care of them or the government fails to provide proper infrastructure due to economic setback, it will have great repercussions on the educational achievement of the young people. Therefore, the present research attempts to find out whether the country's economy influences Nigerian secondary school students' academic performance in Islamic Studies based on their parental background. To this effect, this study aims to address the parental background consisting of education, occupation, income, parental involvement and academic performance specifically in Islamic Studies according to the different gender in North-Central Nigeria in order to derive the causes and the obstacles impeding secondary school students in Nigeria and in the North-Central region in particular.

Several studies have investigated parental background in relation to students' academic performance in various subjects like Mathematics and English, among others (Ajila \& Olutola, 2000; Balogun, 2010; Ojimba, 2013; Aliyu, Ajidagba, \& Rafiu, 2015). It has been further found that, many factors are hampering and obstructing the performance of secondary school students 

DEVELOPMENT

Vol. 7, No. 2, April 2018, E-ISSN: 2226-6348 @ 2018 HRMARS

in Nigeria where the parental background of students is very important. Undoubtedly, the parents are the first teachers of their children where the latter are trained the fundamental moral values of life before they attend any formal educational setting such as schools. However, little attention is given to any empirical research with respect to parental background in fostering students' academic performance in Islamic Studies in the North-Central part of Nigeria Ese (2002) Abdulkadir (2004) Omoegun (2007) Memo, Muhammad and Muhammad (2010). As such, this area is comparatively deprived of information in terms of learners' academic performance, especially in Islamic Studies. It has been established that the performance of students, especially in Islamic Studies, has not been demonstrating much success. Also, a couple of studies have indicated that over $60 \%$ of secondary school students achieve below $C$ grade in Islamic Studies (Abdur-Rafiu, 2014; Usman, 2014). Therefore, this study attempts to examine the difference between the performance of male and female students in Islamic Studies based on their parental background (education, occupation, income, and involvement) in north-central Nigeria. Each of the previous researchers only concentrated on one or two variable and focused on one local government area or the other. The problem noted here is that, it would not be easy to generalize the findings. The present researcher sees the need to carry out a research that would capture the actual situation of the performance of students in the north central geographical zone of Nigeria. Thus, the present study intends to fill the gap in the existing body of knowledge. This finding has also been linked to a comparison between the mean scores achieved by male and female students in connection with their parental background as continuous variables (i.e. education, occupation, income and involvement).

According to Obayan (2003), Olayinka (2004) and Ojimba (2013), parents are the preparatory foundation of any society, community and nation. It is the duty of parents to assist and give their children all the necessary support so that they will be able to become profitable and important citizens of the nation. The outcome of different findings establishes that the academic success of school children is dependent upon the condition of the parental background. Consequently, learners who grow up in high social economic background will perform much better than those who come from low social economic background. The success of these learners is generally associated with a combination of their parents' qualification, occupation and income standard (Jeynes, 2002). Coleman (2008) states that parental background is critically divided into three aspects namely financial capital, human capital and social capital. It is further asserted that financial aspect entails parental income, human capital is associated with parental educational qualification and social capital deals with their relationship with the children. These three aspects of parental background are closely connected with learners' educational performance.

Hanafi (2006) agrees that parents' educational qualification might play an imperative role in defining a child's ability and academic attainment. Meanwhile, literature has shown that with high qualifications, parents are more likely to involve themselves in activities that would develop the cerebral capacity of their children and help them to perform adequately in school (Goni \& Bello, 2016). It is further explained that the academic needs of children at home are mostly satisfied by educated parents who provide the necessary materials for their progenies in order to enable them to perform extra ordinarily in classroom. Furthermore, children's ability to grow is significantly associated with the occupation of parents (Akinsanya, Ajayi \& Salomi, 2011). Gottfried et al. (2004) claim that the majority of parents are encouraged by motivational practices such as making the effort, being curios, having mastery of subject area, and providing 
Vol. 7, No. 2, April 2018, E-ISSN: 2226-6348 ๑ 2018 HRMARS

reinforcement and assessment that can possibly influence students' academic performance. Gutman and Akerman (2008) also assert that children's education is connected with the behaviour and aspiration of parents. It is further suggested that the high desire of parents assists their offspring's achievement. Hill and Craft (2003) confirm that the contribution of parents is an asset of both father and mother for the children's future benefit. Hafiz et al. (2013) expound that with parents' input, children cannot only achieve social and cognitive development but they also develop talent, personality and potential skills.

Not only that, when freedom is established and children are given financial rewards by their parents congruent to their academic performance, they become more assiduous students (Kamau, 2013). Kamau (2013) further asserts that the levels of learners in terms of a standard grading system to a competitive grading system are motivated by each family. Wing and Staver (1997) maintain that male students obtain higher grades than female students in Science. In addition, Lee (1998) and Tamir (1998) state that male students are more prepared to study Maths and Science compared to their female counterparts and accomplish their educational attainments better. Leader (1992) found that difference between males and females in Maths was statistically significant while Tzuriel (2010) affirms that performance in the different areas like Science, Maths and English is often influenced by the gender of the students.

Rampacher and Peterson (1999) and Mondoh (2001) found that male and female students' academic performance in adjacent classes to be significant different. They further reason that the reality of learning is perceived and processed differently as male and female students have their own way of learning in different styles that might influence understanding and academic performance in their educational endeavour. In addition, Boocock (1992) shows certain features are established by the community to discriminate the roles as well as mental, emotional and physical behaviours between males and females which are culturally hypothesized as gender. It is further explained that any affiliation originating between academic attainment and sex must be ascribed to aspect of the stratification process.

In Nigeria, extensive efforts have been made to understand on how gender effects could improve the academic performance of both males and females in integrated Science (Oluyemi \& Muhamme, 2016). The researchers assert that female learners attain greater scores in verbal ability than their counterpart. It is further stated that many literatures have concluded that differences between males and females have not always favoured one gender over the other. Lao (1980) and Young and Fisler (2000) found that male students achieve tremendous Cumulative Grade Point Average (CGPA) scores in Maths classes compared to female students before they enrol into higher educational.

Therefore, a comparative study of male and female Islamic Studies students' academic performance with respect to aspects of their parental background such as education, occupation, income and involvement in North-Central Nigeria is observed to be relevant, especially in the Nigerian context. This study therefore addresses the following research hypotheses:

H1.There is no significant difference between the performance of male and female students in Islamic Studies based on parental education.

H2. There is no significant difference between the performance of male and female students in Islamic Studies based on the occupation of parents.

H3.There is no significant difference between the performance of male and female students in Islamic Studies based on on parental income. 
INTERNATIONAL JOURNAL OF ACADEMIC RESEARCH IN PROGRESSIVE EDUCATION AND DEVELOPMENT

Vol. 7, No. 2, April 2018, E-ISSN: 2226-6348 @ 2018 HRMARS

H4. There is no significant difference between the performance of male and female students in Islamic Studies based on parental involvement.

\section{Methodology}

This paper uses cross- sectional design. Meanwhile, the reason for using this particular design was based on the questionnaire as there was need for data collection for specific time and the data collected from respondents were used for the particular time. Cross-sectional is used in stages. According to Johnson (2011); Check and Schutt (2011) view cross-sectional research is a way of guarding information and sample collected from individual through their responses to an instrument. Furthermore, the entire population of the study consisted of 165,909 individuals and this figure was drawn from the seven states that constitute North-Central geo-political zone of Nigeria. Therefore, Raosoft Sample size calculator was used to select 384 respondents in line with the sample size formula.

Furthermore, a questionnaire was used as the instrument to collect the data. Additionally, the questionnaire was adapted from Ugwuja (2010). It was adapted in order to make it suitable for this study and the instrument was titled as "Students' Questionnaire on Parental Background (SQPB)" with a four-point Likert scale which contains the following elements: 4= strongly agree $(\mathrm{SA}), 3=$ agree (A), 2=disagree (D) and 1=strongly disagree (SD). Empirical research recommends that Likert scale can be used for the purpose of evaluating students' experiences because it is effective in determining the attitudes, easy to construct and manage (Yuksel 2001; Hudson, Hudson \& Miller, 2004; Caruana et al., 2004). Importantly, the questionnaire for this study comprises 35 items on parental education, parental occupation, parental income and parental involvement. The questionnaire is divided into three parts. Part 1 addresses the demographic profile of respondents in the North-Central geo-political zone of Nigeria, Part 2 asks for information on students' home background while Part 3 consists of statements with four items (A-D) of choice.

The face and content validity of the questionnaire was established through the expert opinions of six people from different fields; two experts from Islamic Studies, two experts in the area of measurement and evaluation and two experts from the Language Department which is in line with the submission of extant literature (Wiersman \& Juris, 2005; Creswell, 2005). Reliability of the instrument was also carried out by reporting Cronbach's Alpha for internal consistency of the instrument. A pilot test was conducted whereby the reliability of the instrument was as follows: Academic performance=.810; education=.757; occupation=.748, income $=.765$ and involvement $=.777$. For data analysis, SPSS version 23.0 was used whereby the t-test was used on each aforesaid continuous variable (education, occupation, income and involvement) in connection with gender. 
INTERNATIONAL JOURNAL OF ACADEMIC RESEARCH IN PROGRESSIVE EDUCATION AND DEVELOPMENT

Vol. 7, No. 2, April 2018, E-ISSN: 2226-6348 @ 2018 HRMARS

Table 1: The number of sample

\begin{tabular}{cc}
\hline States & Stratified Random Technique \\
& \\
\hline Abuja & $10,025 \div 165,909 \times 384=23$ \\
Kwara & $21,499 \div 165,909 \times 384=49$ \\
Kogi & $28,128 \div 165,909 \times 384=65$ \\
Benue & $29,842 \div 165,909 \times 384=69$ \\
Nassarawa & $27,924 \div 165,909 \times 384=65$ \\
Niger & $23,193 \div 165,909 \times 384=54$ \\
Plateau & $25,298 \div 165,909 \times 384=59$. \\
& The total number was 384 \\
\hline
\end{tabular}

\section{Results of the Study}

The t-test was used to compare the mean scores of each underlining parental background factor as continuous variables (i.e. education, occupation, income and involvement) for gender whereby males and females were regarded as two different groups for this study. The education background of parents was examined by linking it with gender.

The majority of the respondents were females with 210 (55\%) while males were 174 (45\%). This shows that females were available to the researcher during administration of data. Besides, it can also be understood that female were committed to western education than males in North-Central part of Nigeria. Concerning the respondents age, it is obvious that the majority of the respondents with 367 or 96\%) were between 16 and 20 years old while 17 (4.4\%) were aged between 21 and 25. This indicates that they were capable to be conversant with their parental impact on their academic performance in the North-Central part of the country. Tables 2 and 3 portray the frequencies and percentages of respondents' gender and ages in secondary school in North-Central.

Table 2 Frequency and percentage of respondents' Gender

\begin{tabular}{lll}
\hline Gender & Frequency & Percentages \\
Male & 174 & $45.4 \%$ \\
Female & 210 & $54.7 \%$ \\
Total & 384 & $100 \%$ \\
\hline
\end{tabular}




\begin{tabular}{lll}
\hline \multicolumn{2}{l}{ Table 3 Frequency and percentage of respondents' Ages } \\
\hline & & \\
Respondents' ages & Frequency & Percentages \\
16 to 20 & 367 & $95.6 \%$ \\
21 to 25 & 17 & $4.4 \%$ \\
Total & 384 & $100 \%$ \\
& & \\
\hline
\end{tabular}

\section{Research Hypothesizes}

H1. There is no significant difference between the performance of male and female students In Islamic Studies based on parental education

Table 4 shows Independent Sample Test on Students' Parental Education and

\begin{tabular}{|c|c|c|c|c|c|c|c|c|c|}
\hline \multicolumn{10}{|c|}{ Gender } \\
\hline Gender & $\mathrm{N}$ & & Mean & & $\begin{array}{l}\text { Std. } \\
\text { Deviation }\end{array}$ & t-value & Sig. & \multicolumn{2}{|l|}{ Df } \\
\hline Male & 173 & & $24.739 \mathrm{c}$ & & 5.09520 & \multirow[t]{2}{*}{1.680} & \multirow[t]{2}{*}{.094} & \multirow{2}{*}{\multicolumn{2}{|c|}{381}} \\
\hline Female & 210 & & 23.9667 & & 3.90483 & & & & \\
\hline \multicolumn{10}{|c|}{ Independent Sample Test } \\
\hline \multicolumn{10}{|c|}{$\begin{array}{l}\text { Levene's } \\
\text { Test for } \\
\text { Equality of } \\
\text { Variances }\end{array}$} \\
\hline Education & $\mathrm{F}$ & Sig. & $T$ & Df & $\begin{array}{l}\text { Sig. (2- } \\
\text { tailed) }\end{array}$ & $\begin{array}{c}\text { Mean } \\
\text { Difference }\end{array}$ & $\begin{array}{l}\text { Std. Error } \\
\text { Difference }\end{array}$ & \multicolumn{2}{|c|}{$\begin{array}{l}95 \% \text { Confidence } \\
\text { Interval of the } \\
\text { Difference }\end{array}$} \\
\hline $\begin{array}{c}\text { Equal } \\
\text { variances } \\
\text { assumed }\end{array}$ & .163 & .230 & 1.680 & 381 & .094 & .77322 & .46014 & $\begin{array}{c}\text { Lower } \\
- \\
.13152\end{array}$ & $\begin{array}{c}\text { Upper } \\
1.67796\end{array}$ \\
\hline $\begin{array}{l}\text { Equal } \\
\text { variances } \\
\text { not } \\
\text { assumed }\end{array}$ & & & 1.639 & 317.533 & .102 & .77322 & .47188 & $\begin{array}{c}- \\
.15519\end{array}$ & 1.70163 \\
\hline
\end{tabular}

The results shown in Table 4 found that there is no statistical and significant difference between mean scores for males $(M=24.74: S D=5.09)$ and females $(M=23.96: S D=3.90)$ based on parental education. 2-tailed .094 was found to be greater than 0.05 . Therefore, the hypothesis, which states that There is no significant difference between the performance of male and female students in Islamic Studies based on parental education is rejected. This indicates that there was 
INTERNATIONAL JOURNAL OF ACADEMIC RESEARCH IN PROGRESSIVE EDUCATION AND DEVELOPMENT

Vol. 7, No. 2, April 2018, E-ISSN: 2226-6348 @ 2018 HRMARS

significant difference in the performance of male and female students in Islamic Studies based on parental education.

H2. There is no significant difference between the performance of male and female students In Islamic Studies based on parental occupation

Table 5 shows Independent Sample Test on Students' Parental Occupation and

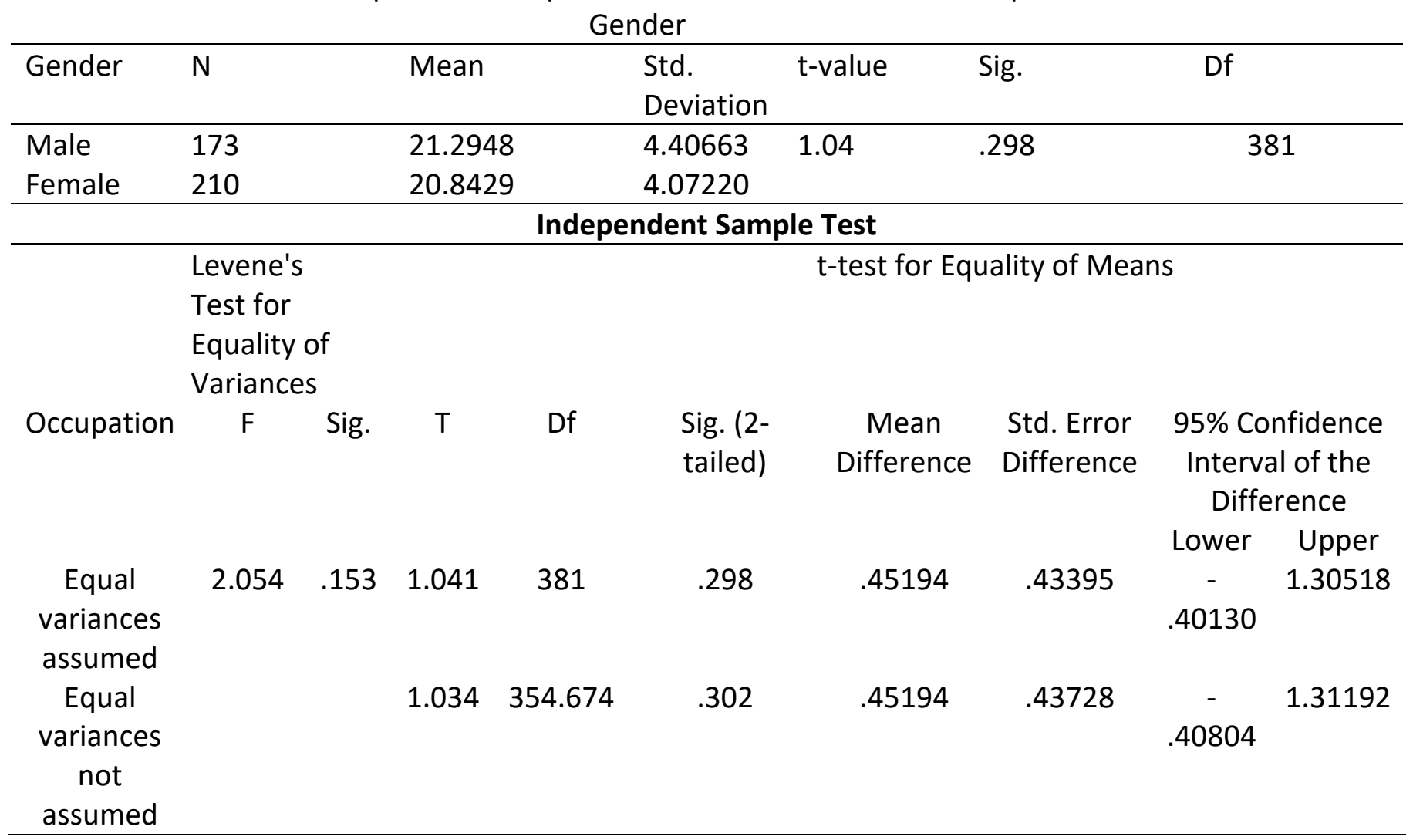

Undeniably, as shown in Table 5, the data acquired from the respondents indicate that there was no significant difference in scores for males $(M=21.29 ; S D=4.40)$ and females $(M=20.84 ; S D=4.07)$ based on parental occupation. Since the 2-tailed of 0.29 was found greater than 0.05 . Thus, Hypothesis 2 is also rejected. Hence, there was no significant difference in the performance of male and female students in Islamic Studies based on parental occupation.

H3. There is no significant difference between the performance of male and female students In Islamic Studies based on parental income 
INTERNATIONAL JOURNAL OF ACADEMIC RESEARCH IN PROGRESSIVE EDUCATION AND DEVELOPMENT

Vol. 7, No. 2, April 2018, E-ISSN: 2226-6348 @ 2018 HRMARS

Table 6 shows Independent Sample Test on Students' Parental Income and

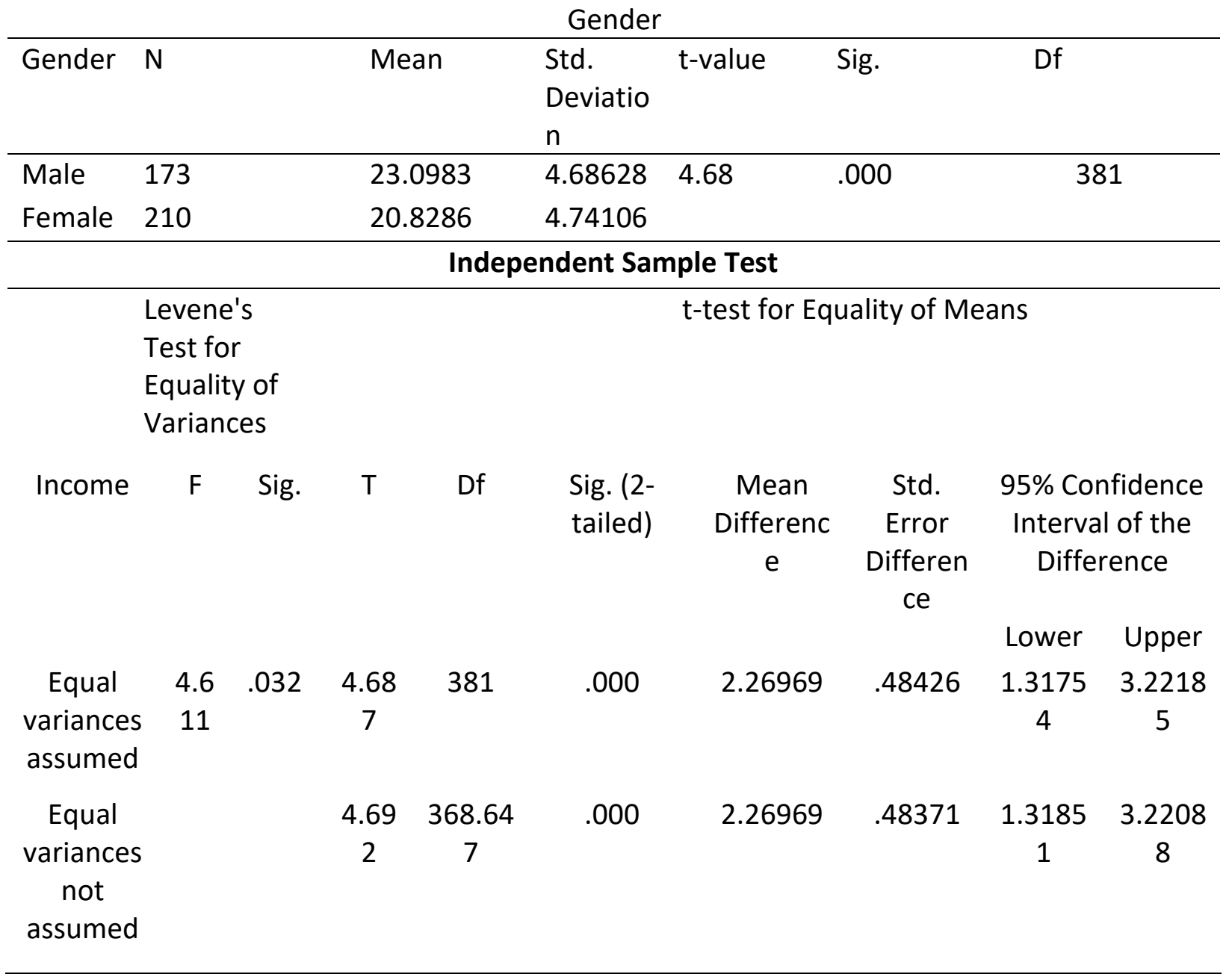

As predicted, results from an independent sample test indicate that the mean score for males $(M=23.09 ; S D=4.68)$ was higher than the score for females $(M=20.82 ; S D=4.74)$ with 2tailed 0.000 which was less than 0.05 . So, Hypothesis 3 is hereby accepted as there was significant difference in the performance of male and female students in Islamic Studies based on parental income.

H4. There is no significant difference between the performance of male and female students In Islamic Studies based on parental involvement 
INTERNATIONAL JOURNAL OF ACADEMIC RESEARCH IN PROGRESSIVE EDUCATION AND DEVELOPMENT

Vol. 7, No. 2, April 2018, E-ISSN: 2226-6348 @ 2018 HRMARS

Table 7 shows Independent Sample Test on Students' Parental Involvement and Gender

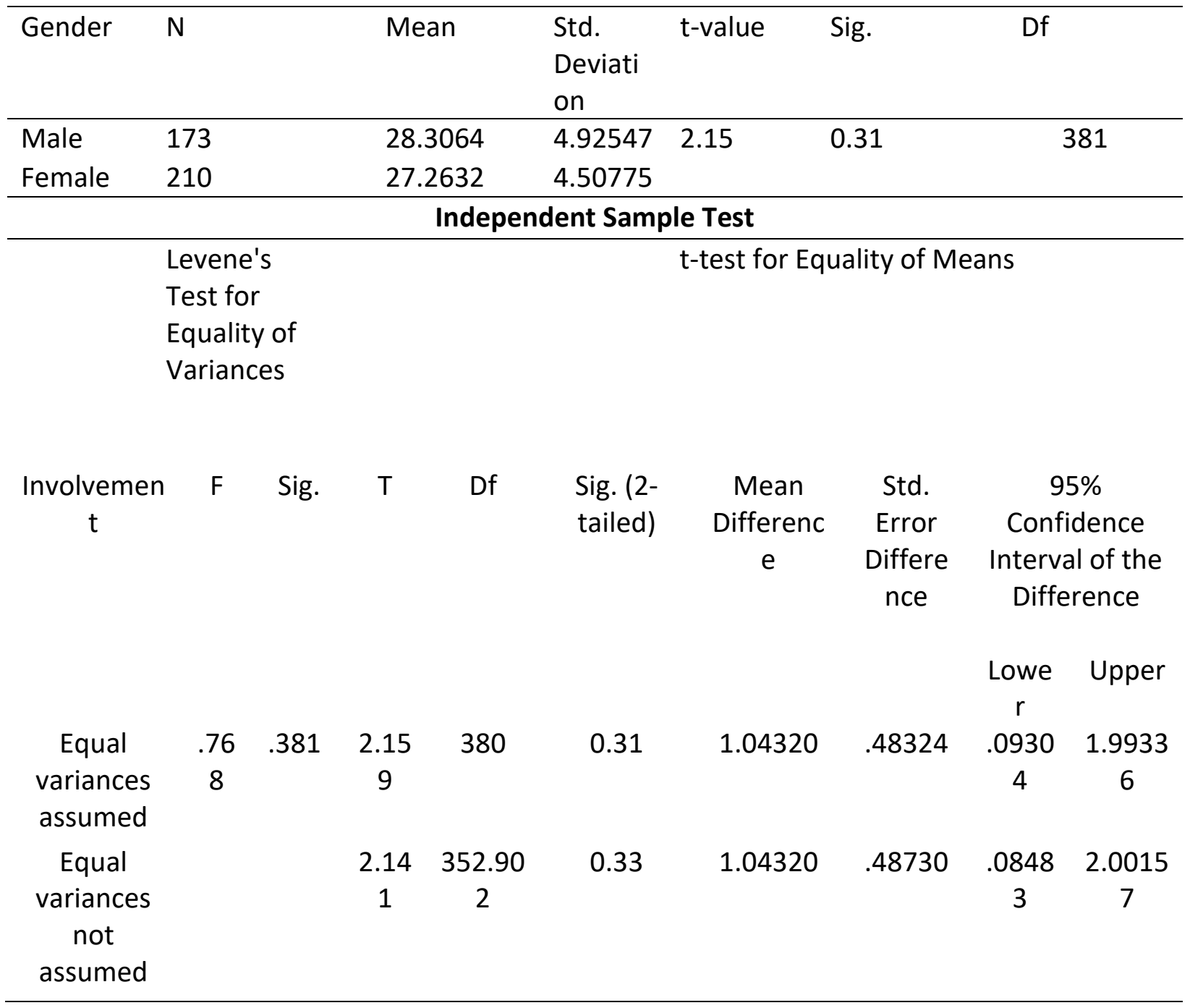

Lastly, there was no significant difference between the mean scores for both male students and female students based on parental involvement. The results of this study show that the value of 2-tailed 0.31 was found to be greater than 0.05 . Therefore, parental involvement for male students was better $(M=28.30 ; S D=4.92)$ than parental involvement for female students $(M=27.26 ; S D=4.50)$ in North-Central part of the country. So, Hypothesis 4 which states that there is no significant difference between the performance of male and female students in Islamic Studies based on parental involvement is absolutely rejected.

\section{Discussion of Finding}

Based on the result of this study, it can be deduced that the performance of male and female students in north-central Nigeria did not make any differences in term of parental (education 0.09>0.05, occupation 0.29>0.05 and involvement 0.31>0.05). It shows from data 
Vol. 7, No. 2, April 2018, E-ISSN: 2226-6348 @ 2018 HRMARS

output that only parental income makes difference between male and female scores Undoubtedly, an independent sample t-test was used to compare scores on students' parental background variables for males and females in secondary schools in the north-central Nigeria. This result collaborates with the findings of Erola, Jalonen, and Lehti, (2016) who made it clear that education obtained by the parent serves as the best tool that explains offspring's performance in school. It is further asserted that students' performance cannot be determined by parental income alone. It also concurs with the results of Singh and Ali Imam (2014) who evidently show that the performance of students increases in Science when the qualification of the father is greatly increased.

This invariably means that there is no discrimination between male and female students with regard to the effects of their parental education on their academic performance. This finding is in line with Goni and Bello, 2016) who avow that there are no variances between male and female students based on socio-economic background of their parents. It is further submitted that there was no disparity between them when argumentative issue was involved where male scores were found to be the same as female scores.

This result collaborates with the findings of Young and Fisler (2000) who confirmed that male students score the same higher Cumulative Grade Point Average (CGPA) scores in Maths with their female counterpart before they enrol into higher education institutions. Similarly, Krashin (2005) observes that both males and females whose father or mother are well-educated get more support from them and achieve better results in examination.

Also, the findings of this paper also highlight that there was no significant difference in the performance of male and female students in Islamic Studies based on parental occupation. Parents who are working as civil servants or non civil servants concentrate on the performance of their children. This is in disagreement with the study by Wing and Staver (1997) who maintain that male children obtain higher grades than females in Science if they have parents who are civil servants. Moreover, Lee (1998) and Tamir (1998) found that male learners were more ready to study Maths and Science because of the prestigious jobs of their parents than their female counterparts; they were also more like to accomplish better educational attainments.

Consequently, the results also reveal that there was a significant difference in the performance of male and female students in Islamic Studies based on parental income. Male students were given more financial backing or support than their female colleagues. This corroborates with Kamau (2013) who espouses that when freedom is established and children are given financial rewards by their parents because of their academic performance, they become less assiduous. This also agrees with the conclusion of Ahmad al.et (2015) who reveal that the most crucial factor that enhances male performance is better income support. They further emphasize that parents spend precious time and money for males more than for females.

In addition, the result of this paper exposes the fact that there was no significant difference between the mean scores for both male students and female students based on parental involvement. It is shown that the parents are more involved in their both male and female children, positively affecting their academic performance in Islamic Studies than in NorthCentral Nigeria. This outcome is in line with the study by Gutman and Akerman (2008) who assert that children's education is connected with the behaviour and aspiration of parents. They further suggest that the high desire of parents will assist their offspring's achievement. This also supports the findings of Hill and Craft (2003) who establish and confirm that the contribution of parents is 
Vol. 7, No. 2, April 2018, E-ISSN: 2226-6348 @ 2018 HRMARS

an asset prepared by both father and mother for the children's future benefit. It also coincides with the outcome of Hafiz et al. (2013) who illustrate that with parents' input, children cannot only achieve social and cognitive development but also develop talent, personality and potential skills.

\section{Conclusion of Major Findings}

Many findings show that parental background have related to students' educational outcome and it also plays a crucial role to redefine the students' academic performance in various subjects Therefore, this led the researcher to reveal that, to make students to be successful in their careers, many factors are to be considered. These factors indicate the level of parents' education, prestigious occupation of parents, income level of parents and involvement of parents in their children's education are capable of enhancing academic performance of students especially in Islamic Studies. Nevertheless, The performance of both male and female secondary school students have been found to be in significantly different irrespective of parental educational background, occupation and involvement especially in Islamic Studies in NorthCentral Nigeria. It shows from data output that only parental income makes difference between male and female scores. Female students are given less support unlike male students based on parental income. Moreover, both male and female children get a lot of advantage if they have parents who have good educational background. Additionally, parents who are working as civil servants or non civil servants concentrate on the performance of their children enormously. The outcome of the paper discloses that parental income support was able to help male children in school but not for female children. In the same vein, this result also reveals that male learners were getting support from their parents more than female learners. The results show that there are countless methods in which parents are involved in their children's education attainment but their academic performance may differ.

\section{Implication of the Study}

This study contributes to existing knowledge by comparing academic performance of male and female students in Islamic Studies based on dimensions of parental background such as education, occupation, income, and involvement in north-central geo-political zone of Nigeria. Also, this study also contributes to the knowledge by covering the north-central that constitutes of seven states which was not applied in the previous studies.

\section{Recommendations}

It is recommended that the government, school management, Islamic Studies teachers and parents should play collaborative roles on female education in order to boost their performance in Islamic Studies in secondary schools in North-Central Nigeria. Irrespective of the learners' parental background, parents should also assist and encourage their female students in leading them towards achieving outstanding academic performance in Islamic Studies in secondary schools in North-Central Nigeria. This study employed quantitative design by examining the difference between the performance of male and female students in Islamic Studies based on their parental background (education, occupation, income, and involvement) in north-central Nigeria the further studies should employ qualitative and mixed method research designs mainly 
INTERNATIONAL JOURNAL OF ACADEMIC RESEARCH IN PROGRESSIVE EDUCATION AND DEVELOPMENT

Vol. 7, No. 2, April 2018, E-ISSN: 2226-6348 @ 2018 HRMARS

to have in-depth understanding of parental influence on students' academic performance in Islamic Studies

\section{References}

Gottfried, E. A.; Fleming, S. J.; Gottfried, W. A. (1994). Role of Parental Motivational Practices in Children's Academic Intrinsic Motivation and Achievement. Journal of Educational

Gutman, L.M. and Akerman, R. (2008). Determinants of Aspirations. Centre for Research on The Wider Benefits of Learning Research Report 27. London. Institute of Education

Hafiz, H. M. W., Tehsin, F., Malik, M. S., Muhammad, S., \& Muhammad, A. K. (2013) Parental Involvement and academic achievement: A study of secondary school students of Lahore, Pakistan. International Journal of Humanities and Social Science, 3(8), 209-223.

Hill, N. E., \& Craft, S. A. (2003). Parent-school involvement and school performance: Mediated Pathways among socioeconomically comparable African American and Euro-American Families Journal of Educational Psychology, 95(1), 74.

Jeynes, W. H. (2002). Examining the effects of parental absence on the academic Achievement of adolescents: the challenge of controlling for family income. Journal of Family and Economic Issues 23(2).

Goni, U. and Bello, S. (2016).Parental Socio-Economic Status, Self-Concept and Gender Differences on Students' Academic Performance in Borno State Colleges of Education: Implications for Counseling: Journal of Education and Practice www.iiste.org ISSN 22221735 (Paper) ISSN 2222-288X (Online) Vol.7, No.14, 2016

Lao, R. C. (1980). Differential Factors Affecting Male and Female Academic Performance in High School, The Journal of Psychology, 104, pp.119-127.

Manning, M. L. (1998), Gender differences in young adolescents' Mathematics and science Achievement, childhood education Article.

Mondoh, H.O. (2001). A comparison of activities carried out by boys and girls during their free time in relation to their achievement in mathematics. A case of Eldoret municipality, Kenya. Journal of Education and Human Resources, 1, 49-56.

Obayan, O.A. (2003). Father infant and mother infant interaction in the first year of life. Child development 48 (1) $177-18$.

Ojimba, D. P. (2013). Home Background and Senior Secondary Students' Achievement in Mathematics in Rivers State, Nigeria. Journal of Educational and Social Research, 3(2), 
INTERNATIONAL JOURNAL OF ACADEMIC RESEARCH IN PROGRESSIVE EDUCATION AND DEVELOPMENT

Vol. 7, No. 2, April 2018, E-ISSN: 2226-6348 @ 2018 HRMARS 283.

Olayinka, M.O. (2004). Promoting family ethics and integrity. Lagos: Macmillan Publisher.

Oluyemi J. A. \& Muhammed A. Y. (2016) Girl-Child Education in Nigeria: Issues and Implications on National Development Zimbabwe Ibubnal Bf Educational Beseabch Volume 28 Number 1 March 2016

Singh, S.P., \& Imam, A. (2014) Effect of Gender, Attitude towards Science, Parental Education And Family Size on Science Achievement of Secondary School Students of Central U.P. International Journal of Advancements in Research \& Technology, Volume 3, Issue 2, February -2014 47 ISSN 2278-7763

Pimchas, T. (1998) Gender differences in high school sciences in Israel -el, British Educational Research Journal

Young, J. W. and Fisler, J. L. (2000). Sex Differences on the SAT: An Analysis of Demographic And Educational Variables, Research in Higher Education, 41, pp. 401-416. 